\title{
EXAMPLES OF DEVELOPMENT OF ELECTROMOBILITY IN PUBLIC TRANSPORT IN POLAND
}

\section{ZUZANNA KŁOS-ADAMKIEWICZ}

University of Szczecin, Faculty of Management and Economics of Services, POLAND e-mail: zuzanna.klos@wzieu.pl

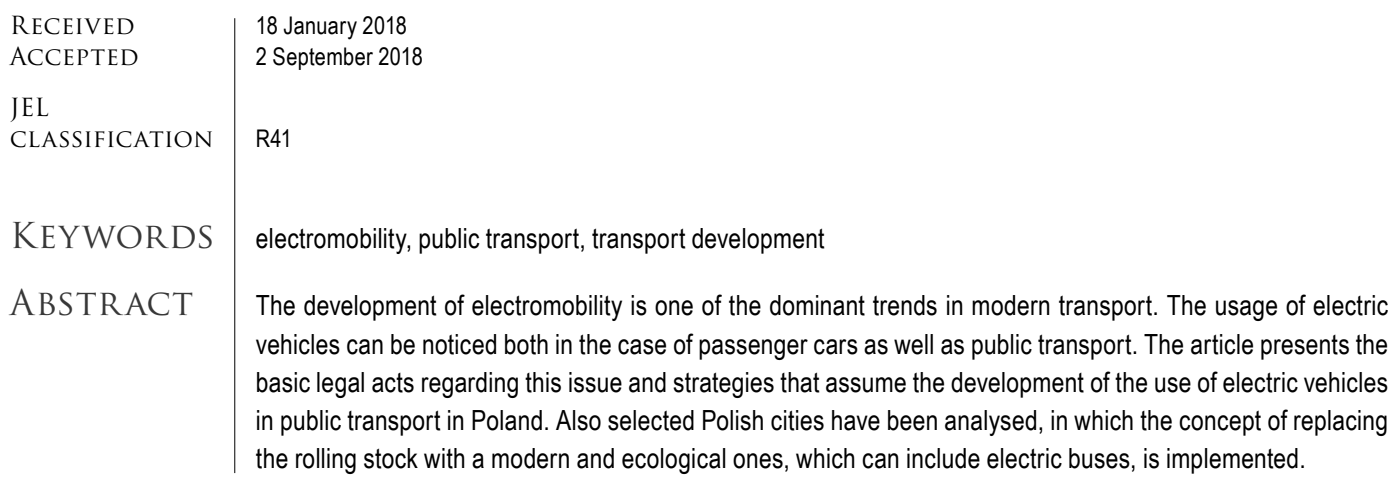
vehicles can be noticed both in the case of passenger cars as well as public transport. The article presents the basic legal acts regarding this issue and strategies that assume the development of the use of electric vehicles in public transport in Poland. Also selected Polish cities have been analysed, in which the concept of replacing the rolling stock with a modern and ecological ones, which can include electric buses, is implemented.

\section{Introduction}

Nowadays, almost whole Europe faces the challenge of changes in the natural environment, including climate, air and noise. The policies of European and national authorities impose more stringent norms on environmental protection, while local and regional authorities remain in their implementation. Transport is one of the sectors that 
contributes the most to the above problems, and at the same time is a basic element of efficiently and effectively functioning cities.

Electric vehicles and broadly understood electromobility enable taking action in the fight against the negative effects of using vehicles with conventional propulsion (having mainly internal combustion engines) without limiting the important role that vehicles- passenger cars as well as public transport vehicles fulfil.

One of the main barriers to the growth of electromobility is the fact that no correct business models have yet been developed, thanks to which it is possible to assess to what extent new projects in this area will guarantee a source of revenues and funds allocated for the projects will be secured. Currently, electric vehicles have higher initial investment costs compared to traditional vehicles and require proper adaptation of the infrastructure (mainly point-based) used for charging. In this respect, numerous initiatives are taken into account that involve the involvement of producers, service providers, information and communication technology (ICT) enterprises, research centres and other entities aimed at creating innovative models for electromobility solutions (EVUE, 2013).

\section{Creating principles of electromobility in Poland's transport policy}

The origins of issues related to the development of electromobility in public transport in Poland should be sought in the National Municipal Policy (Krajowa Polityka Miejska, 2015), which indicates the adoption of actions affecting the use of more environmentally friendly vehicles and the promotion of the use of electric cars (Krajowa Polityka Miejska, 2015). Attention was drawn to the fact that city authorities should create trends by introducing into service public transport of rolling stock equipped with ecological propulsion units or using ecological power methods.

Another important document related to public transport issues is the Act on public transport (Ustawa o publicznym transporcie zbiorowym, 2010). It contains an interpretation of the sustainable development of public transport, which takes into account modern and also promoting environmentally friendly modes of transport, but yet no reference is made directly to the use of electric vehicles (Ustawa, 2010).

Work on the development of electromobility in Poland has gained momentum in 2016. In July 2016, the Strategy for Responsible Development (Strategia na rzecz Odpowiedzialnego Rozwoju - SOR) was published, which is to set the path of Polish development until 2020, where priority issues regarding public transport were also included. The project places a strong emphasis on electromobility as well as on the development of integrated public transport in cities using low-emission vehicles.

The main aim of the SOR is to "create conditions for the growth of incomes of Polish citizens with simultaneous increase in cohesion in the social, economic, environmental and territorial dimension". As part of the implementation of the main aim, three specific aims were included (Strategia, 2017, pp. 51-55):

1. Specific aim 1 - Sustainable economic growth based more on knowledge, data and organizational excellence.

2. Specific aim 2 - Socially sensitive and territorially balanced development.

3. Specific aim 3 - An effective country and institutions for growth and social and economic inclusion.

The first specific aim concerns, to a large extent, the issues of electromobility, including reindustrialisation (this area concerns the sector of producing transport means). Detailed objectives include programs, and theseflagship projects. Electromobility is one of the programs, it concerns the development of products in the field 
of electromobility and market stimulation in such a way as to increase the share of electric vehicles. The program includes two flagship projects (Strategia, 2017)

a) e-bus -stimulating the design and production of Polish electric vehicles for the needs of public transport and building strong entities at all stages of the value chain in the urban transport fleet production sector (electric buses and trams). The implementation of the program assumes that by 2025 (12):

- the Polish electric bus market will be created with a value of at least 2.5 billion PLN annually, gives approx. 1,000 electric buses,

- a Polish Electric Bus market will be created, whose key elements will be produced inside the country,

- new technologies and business models related to urban electric buses and charging infrastructure will be developed;

b) electric car - for stimulating the development of technology, production and the market for electric cars. It mainly concerns the production of small city cars and activities related to the introduction of many facilities for electric car owners (mainly in the area of taxes and prices) (12).

Another project is Luxtorpeda 2.0, which is designed to stimulate the development of technology, the production of Polish rail vehicles, with particular emphasis on passenger transport vehicles.

In its final version, SOR assumes public support, which aims at the development of integrated public transport systems using low-emission means of transport, mainly rail vehicles and electric buses. Actions aimed at increasing the importance of rail in the cities (agglomeration railways), which should be integrated with public transport (mainly in the area of tariffs and a joint ticket), were also indicated. The SOR assumes a gradual exchange of the public transport fleet for low-emission vehicles by 2025 , which also involves the need to build low-emission charging systems and networks.

Other activities related to the development of electromobility included in SOR relate to the Non-Waste Public Transport program, which was initiated at the beginning of 2017 at the Ministry of Science and Higher Education. The goal of the program is to implement innovative solutions for electromobility as part of an innovative partnership. It is one of the elements of activities within the SOR. The assumptions of the program are based on the role of the state as an intelligent contracting party, cooperation with local governments and creating innovative products. Such consortia, in which both scientific institutions and private sector producers can be found, can count up to 100 million PLN for project implementation and, at a later stage, for a sales market to be created by local governments. It is also estimated that transactions carried out under the program will reach up to 1 billion PLN, and up to 50 local governments may receive even 1,000 modern vehicles (the first purchases scheduled for 2019) (Jaworzno będzie..., 2016).

\section{The cost of purchasing electric vehicles in Poland}

Until now, Polish cities and municipalities mainly tested electric buses. Currently, they are slowly starting to buy and create lines on which only clean vehicles will operate. However, there are still many problems associated with the purchase and operation of this type of vehicles, which are (Krupa, Kamiński, 2017, p. 3):

- long decision-making paths and numerous procedures that involve the construction of infrastructure, including a complex system of building permits and other related charging systems,

- the problem of the division of competences between entities such as transport companies, the city and electricity distribution companies, 
- costs of purchasing electric vehicles,

- strong competition from Chinese bus companies that offer their vehicles at very low prices,

- construction of an appropriate charging infrastructure.

In Poland, about 1,000 city buses are exchanged every year, which may create chances to create demand for new electric buses. An example of these actions is: Miejskie Zakłady Autobusowe in Warsaw and Miejski Zakład Komunikacji in Zielona Góra, which plan, in total, the purchase of around 200 electric buses (Krupa, Kamiński, 2017, p. 5). The average market price of an electric bus is around 2 million PLN. It can be also assumed that the price of an electric bus is from 75 to $180 \%$ higher. ${ }^{1}$ Therefore, many cities decide to purchase electric buses and apply for their financing.

Despite the high costs of purchasing an electric bus, many cities decide to do so, since assuming that the electric bus will travel for $300 \mathrm{~km}$, the investment in their purchase can pay back after 10 years, as is the case with buses with a diesel engine (Stawski, Ziaja, 2016, p. 4). This task is to be facilitated by pantograph loaders, which are arranged on loops and stops (Table 1).

Table 1. Examples of electric bus prices and operating costs

\begin{tabular}{ccl}
\hline \multicolumn{1}{c}{ Type of a bus } & \multicolumn{1}{c}{ Price } & \multicolumn{1}{c}{ Operating costs } \\
\hline BYD (Build Your Dreams) & Approx. 1.6 billion PLN & $\begin{array}{l}\text { The cost of covering 100 km for a battery-powered bus is about 50 PLN, whereas traditional } \\
\text { combustion cars consume about } 40 \text { litres of fuel at the same distance, which costs over } \\
200 \text { PLN. Assuming that the bus covers about } 300 \mathrm{~km} \text { a day, the savings may reach up to } \\
160,000 \mathrm{PLN} \text { a year }\end{array}$ \\
\hline Solaris Urbino 12 Electric & Approx. 2.2 billion PLN & $\begin{array}{l}\text { The Solaris Urbino 12 Electric consumes about 1.35 kWh of energy. A journey of } 100 \\
\text { kilometres costs four times less than in the case of the classic Solaris Urbino 12 (which } \\
\text { consumes about 40 litres of diesel per 100 kilometres) }\end{array}$ \\
\hline
\end{tabular}

Source: own elaboration based on: Krupa, Kamiński (2017); Elektromobilność w Polsce... (2017).

Currently, buses on one charge can travel about $120 \mathrm{~km}$, while a larger range requires larger batteries (solution proposed by BYD), but this has an influence on the vehicle capacity resulting from the need to place a larger battery (ZeEUS eBus Report..., 2018).

\section{Examples of implementing solutions in the field of electromobility in public transport in Polish cities}

Currently, most Polish cities are plan or implement various solutions in the field of electromobility. There are many reasons for the development of this type of ecological transport. One can mention, among others, such issues as the increasing number of population in cities, which often translates into increased daily mobility of residents deciding to choose a specific means of transport (usually a car or public transport). The authorities' task is to encourage the use of public transport (in accordance with the principles of sustainable transport development), as well as taking action to meet the requirements in the social, ecological and economic area with these modes of transport. City authorities are paying more and more attention to improving the quality of life of residents, hence the creation of ecological and friendly public transport is slowly becoming the norm.

${ }^{1}$ For comparison, bought in 2011 by ZKM Gdańsk Mercedes-Benz cost slightly more than 950,000 PLN per piece. /www. srodowisko.abc.com.pl/czytaj/-/artykul/elektryczny-autobus-drozsza-cena-tansza-eksploatacja (23.03.2018). 
In 2015, almost 12,000 public transport buses were used in Poland, of which only 419 were vehicles with an alternative drive (gas or electric) (Jaworzno w programie..., 2017). At the end of 2016, electric buses accounted for $0.3 \%$ of all buses servicing in public transport in Polish cities, in total, at that time, 21 e-buses were used in 5 Polish cities: Warsaw (10 electric buses), Kraków (5), Inowrocław (2), Jaworzno (2), Łódź (1) and Lublin (1). According to the plans of Polish local governments and governmental forecasts, in five years' time, around 1,000 buses with electric drive will travel along the streets of Polish cities and communes. Examples of the development of electromobility in public transport in Polish cities are presented below.

\section{Warsaw}

Warsaw, to the greatest extent from all Polish cities, is involved in the process of replacing buses with electric ones, as well as with other cities, has the largest number of buses.

The largest Warsaw bus carrier is Miejskie Zakłady Autobusowe (MZA) servicing bus lines within the Warsaw agglomeration. The organizer of transport is the Public Transport Authority in Warsaw (ZTM). Testing of electric buses in Warsaw has been implemented since 2012. The first purchases of electric buses in Warsaw was made in 2014, when two manufacturers applied for a tender for the supply of 10 such vehicles: BYD Europe Rotterdam Holland manufacturing buses in China and Polish Solaris. Ultimately, since 2015, 10 electric buses (Solaris) have been running on Warsaw streets, while from November 2014 to December 2016, 9 BYD buses have been tested (ZeEUS eBus Report, 2018). In 2017, they were joined by another 10 buses, the supplier of which was the Ursus A.A., AMZ Kutno and Ursus Bus (Urbanowicz, 2016) consortium.

Warsaw along with nine other cities (including Barcelona, Paris and Oslo) takes part in the ZeEUS project (Zero Emission Urban Bus System), under which it tests various solutions for electric buses.

Warsaw plans for a low-carbon transport fleet assume that by 2020, 130 electric buses will be used, of which 100 will be articulated. However, in order to use the electric buses, it is necessary to place the appropriate point infrastructure in the form of chargers adapted for charging buses. It is expected that such infrastructure should stand in Warsaw by 2020 in the number of 19 devices. In the nearest future, the city authorities plan that the bus routes in Krakowskie Przedmieście and Nowy Świat will be served exclusively by ecological buses.

\section{Silesian conurbation}

In the area of the Silesian conurbation, it is worth paying attention to the example of Jaworzno, the only city in this area that owns and develops the concept of using electric buses. In this city, research and development works aimed at testing electric vehicles are carried out very intensively. TAURON Dystrybucja and Przedsiębiorstwo Komunikacji Miejskiej (PKM) in Jaworzno started cooperation in the field of research and development of electric bus charging technology. The companies plan to carry out annual tests of the electric vehicle and charging infrastructure in normal operation. Cooperation between companies will be aimed primarily at carrying out research work in the field of charging infrastructure for urban electric bus systems (Jaworzno będzie ..., 2016). In addition, the city' authorities plan to increase the number of ecological vehicles. Currently, among 60 buses that are part of the PKM, one is electric. At the moment, the city applied for co-financing for the purchase of 22 electric buses together with the necessary infrastructure. In October 2016, a contract was signed with Solaris for the supply of 16 electric buses, which were delivered in 2017, as well as in 2016 , the tender procedures for the delivery of another six buses 
also by Solaris were completed. As a result of the actions taken, every third bus in the PKM fleet will be a completely zero emission vehicle (Warszawa: Podpisano..., 2016).

\section{Kraków}

This city pays a lot of attention to environmental issues related to the functioning of public transport. One of the actions undertaken in this field is the electrification of the bus fleet. Miejskie Przedsiębiorstwo Komunikacyjne (MPK) in Krakow has a total of 500 buses and for the moment 5 of them are electrobuses. After a two-year period of testing modern buses, it was decided to purchase them. In 2017, another 20 Solaris electric buses appeared on the streets (MPK w Krakowie..., 2016). The purchase of these buses was possible thanks to the support of EU funds (Regional Operational Program for the Małopolskie Voivodeship for 2014-2020), which enabled co-financing at the level of $85 \%$. Bus charging is provided both with the use of plug-in technology (located on the depot) as well as pantographs (located at special points supplied from tram traction). Ultimately, MPK in Kraków plans to use about 50 electric buses by 2020 .

\section{Lublin}

Lublin, a city in which both buses and trolleybuses are operating, began testing electric buses in 2015. At that time, Ursus Ekovolt started being used by Miejskie Przedsiębiorstwo Komunikacyjne (MPK) in Lublin. Considering the ecological dimension of the use of trolleybuses, it should be mentioned that there are 50 such vehicles in the Public Transport Authority (ZTM) in Lublin. ZTM is planning an additional purchase of 67 electrobuses, of which the most certain is the purchase of 32 vehicles, and 35 more in the so-called. "reserve projects" (ZeEUS eBus Report..., 2018).

In mid-2016, the Cracow company EC Engineering prepared an innovative electric bus charging system, which is being tested in Lublin today. The innovation of this idea consists in a significant (tenfold) shortening of the vehicle's charging time based on technological solutions concerning the power collection system. An innovative charging station was installed at MPK Lublin and, in cooperation with Ursus, a new power collection system was installed on the Ursus Ekovolt vehicle used in the city.

\section{Conclusions}

Many European cities plan to buy only zero-emission buses in the future. This is mainly due to the reduction of the level of environmental pollution and other benefits of using these vehicles, including emission-free in the place of their use (despite the use of energy from coal-fired power plants, the level of pollution is much lower than in the case of buses with traditional, internal combustion), smooth driving and quiet operation (which is important from the point of view of noise in urban areas). The biggest disadvantage is the mentioned high price, however, cities that had the opportunity to test electric buses point out that the operating costs are much lower and the purchase of such buses is economically justified, as it is compensated by savings resulting from cheaper operation.

\section{References}

EVUE. Elektryczne pojazdy w miejskiej Europie (2018). URBACT. Retrieved from: https://www.ure.gov.pl/pl/urzad/informacje-ogolne/ aktualnosci/5250,Elektryczne-Pojazdy-w-Miejskiej-Europie-EVUE-Raport-Koncowy-z-realizacji-projekt.html.

http://www.ncbr.gov.pl/fundusze-europejskie/poir/emobility/ (21.03.2018). 
Jaworzno będzie mieć nowe autobusy elektryczne (2016). Retrieved from: www.pkm.jaworzno.pl/www/2016/10/umowa-na-dostawenowych-autobusow-podpisana.

Jaworzno w Programie Rozwoju Elektromobilności (2017). Retrieved from: www.transport-publiczny.pl/wiadomosci/jaworzno-wprogramie-rozwoju-elektromobilnosci-54394.html.

Kozłowski, K. (2013). Elektryczny autobus: droższa cena, tańsza eksploatacja. Retrieved from: www.srodowisko.abc.com.pl/czytaj/-/ artykul/elektryczny-autobus-drozsza-cena-tansza-eksploatacja.

Krajowa Polityka Miejska 2023 (2018). Retrieved from: https://www.mr.gov.pl/media/10252/Krajowa_Polityka_Miejska_20-10-2015.pdf.

Krupa, K., Kamiński, J. (2017). Analiza wpływu rozwoju elektromobilności na zużycie energii elektrycznej w Polsce. Rynek Energii, 6 , 8-13.

MPK w Krakowie z umową na 20 elektrycznych Solarisów (2016). Retrieved from: www.transport-publiczny.pl/wiadomosci/mpk-wkrakowie-kupuje-20-elektrycznych--solarisow-53225.html.

Najnowocześniejszy autobus elektryczny trafi do Warszawy! (2017). Retrieved from: http://warszawa.naszemiasto.pl/artykul/ najnowoczesniejszy-autobus-elektryczny-trafi-do-warszawy,3984558,art,t,id,tm.html.

Notatka informacyjna dla Komisji Gospodarki Narodowej i Innowacyjności Senatu RP dot. Możliwości rozwoju produkcji autobusów elektrycznych w Polsce. (2016). Ministerstwo Rozwoju, Warszawa. Retrieved from: https://www.senat.gov.pl/gfx/senat/ userfiles/_public/k9/komisje/2016/kgni/materialy/048/2016-09-30_notatka_informacyjna_dla_kgni.pdf.

PlannarzeczOdpowiedzialnegoRozwoju(2017).Retrievedfrom:https://www.mr.gov.pl/strony/plan-na-rzecz-odpowiedzialnego-rozwoju/ informacje-0-strategii.

Program E-bus: Polski Autobus Elektryczny (2017). Retrieved from: https://www.mr.gov.pl/strony/plan-na-rzecz-odpowiedzialnegorozwoju/kluczowe-projekty/program-e-bus-polski-autobus-elektryczny.

Stawski, P., Ziaja, E. (2016). Hybrydowe układy zasilania stacji ładowania pojazdów elektrycznych. Energetyka, 12, 757-760.

Strategia na rzecz odpowiedzialnego rozwoju do roku 2020 (z perspektywą do 2030 r.) (2017). Warszawa: Ministerstwo Rozwoju.

Urbanowicz, W. (2016). Plan Morawieckiego: Mniej aut, elektromobilność i lepszy transport w miastach Retrieved from: /www.transportpubliczny.pl/wiadomosci/plan-morawieckiego-elektromobilnosc-lepszy-transport-i-mniej-aut-w-miastach-52649.html.

Ustawa z dnia 16 grudnia 2010 r. o publicznym transporcie zbiorowym, Dz.U. 2011, nr 5, poz. 13.

Warszawa: Podpisano umowę na dostawę 10 autobusów elektrycznych (2016). Retrieved from: www.portalsamorzadowy.pl/ gospodarka-komunalna/warszawa-podpisano-umowe-na-dostawe-10-autobusow-elektrycznych,86839.html.

Witek, A. (2014). Pierwsze elektryczne autobusy w Warszawie pojawią się za pół roku. Retrieved from: http://warszawa.naszemiasto.pl/ artykul/pierwsze-elektryczne-autobusy-w-warszawie-pojawia-sie-za,2155781,art,t,id,tm.html.

ZeEUS eBus Report. An overview of electric buses in Europe. (2018). Retrieved from: http://zeeus.eu/uploads/publications/documents/ zeeus-ebus-report-internet.pdf.

Zespół Doradców Gospodarczych ZDG TOR (2017). Elektromobilność w Polsce. Perspektywy rozwoju, szanse i zagrożenia. Warszawa. Retrieved from: https://media.efl.pl/reports/18406.

Cite this anticle aS: Kłos-Adamkiewicz, Z. (2018). Examples of development of electromobility in public transport in Poland. European Journal of Service Management, 3 (27/2), 197-203. DOI: 10.18276/ejsm.2018.27/2-24. 